Delta Journal of Science

Available online at https://djs.journals.ekb.eg/

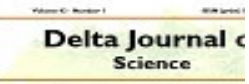

$f(x)$ is

mitranis.

\title{
Natural pozzolans-like Bahariya basalts used as alternative raw materials for cement clinker Portland
}

\author{
Hatem M. El-Desoky ${ }^{1}$, Ahmed E. Khalil ${ }^{2}$, Taher M. Shahin ${ }^{1, *}$ and Ahmed M. Abdullah ${ }^{3}$ \\ 1. Geology Department, Faculty of Science, Al-Azhar University, PO Box 11884, Nasr City, Cairo, Egypt. \\ 2. Geological Sciences Department, National Research Centre, El-Buhouth St., Dokki, Cairo 12622, Egypt. \\ 3. Geologist at El-Qawmiya cement industry.
}

*Corresponding author: Taher M. Shahinｅ-mail: taher_gc@azhar.edu.eg

\section{KEY WORDS}

Basalt, alternative material, clinker, Bahariya, Western Desert, Egypt.

\section{ABSTRACT}

Mid-Tertiary volcanism in the Western Desert Egypt was associated with the opening of the Red Sea, a period of $30 \mathrm{Ma}$. Basalts are composed of plagioclase, pyroxene, and olivine minerals. Basalt used as natural volcanic pozzolans materials; represent large interest of researches as a real alternative to replace ordinary Portland cement (OPC). The present work was performed on six samples of experimental cement clinker, one with ordinary raw materials (limestone $\&$ shale) as a reference sample, and five others with various substance (limestone \& basalts), which show the possibility of the utilization of natural pozzolan for maintainable construction material. The chemical, mineralogical composition and texture produced clinkers were determined by scanning electron microscopy (SEM-EDS), X-ray diffraction (XRD) and differential thermal analysis (DTA). It is concluded that the produced clinkers which made from basalt are coincidence ordinary Portland cement clinker. They are characterized by increasing in setting time, compressive strength and resistance to sulfate attack. 


\section{INTRODUCTION}

Portland cement is the most wellknown kind cement of construction materials, created by heating limestone and clay minerals in a furnace up to $\sim 1450^{\circ} \mathrm{C}$ to form clinker, crushing the clinker, and adding 2 to 3 percent of gypsum. Cement manufacture causes environmental pollution, 1 ton of cement will around produce 1 ton of $\mathrm{CO}_{2}$ (Van Oss and Padovani, 2003 and Uzal, et al., 2007), so sustainable improvement has interest to use alternatives materials.

A pozzolan is a siliceous or aluminous siliceous material that possesses a little or no cementitious value; chemically react with calcium hydroxide to form compounds possessing hydraulic cementitious properties (Mehta, 1987). Natural pozzolans (volcanic origin) are used for several thousands of years as supplementary cementitious materials. Also, it used to control temperature rise in mass concrete, and improve resistance to sulfate attack. Natural pozzolans are generally utilized as substitutes for Portland cement, due to their advantages of cost reduction and increased durability (Papadakis and Tsimas, 2002; Rodríguez-Camacho and Uribe-Afif, 2002; Uzal, et al., 2007). Recently, natural basaltic pozzolan substituted about 25 mass\% of Portland cement from Saudi Arabia (Khan and Alhozaimy, 2010). Reduction of free lime indicates increase in burnability with increasing basalt contents, confirming that basalts are suitable for clinker production, also lowering of clinker formation temperature and reducing $\mathrm{CO}_{2}$ emissions (Andrade et al., 2010).
The volcanic Tertiary basalts are widely distributed in the Eastern Desert, Western Desert and Sinai Peninsula associated with the opening of the Red Sea rift (Bayoumi and Sabri, 1971; Said, 1981 and Williams and Small, 1984). Basalt has wide utilized as concrete aggregate, filtering agent, fibers and pozzolan materials.

Hassaan (2001), El-Ashkar (2002), Hassaan et al. (2004), Abd El-Hafiz et al. (2015), El-Desoky et al. (2017), ElDesoky et al. (2019), El-Rahmany (2019) and El-Rahmany et al. (2020) have utilized gabbroic and basaltic rocks in different areas in Egypt as an alternative to shale in the cement industry. The present work aims to assessment the suitability of using the Bahariya basaltic rocks as ordinary cement raw mix substituting for the shales in a laboratory scale.

\section{Regional geology}

Bahariya oasis is located in the Western Desert of Egypt at about $160 \mathrm{Km}$ west of the Minya city in the Nile Valley, between $27^{\circ} 48^{\prime}$ and $28^{\circ} 30^{\prime} \mathrm{N}$ latitude and $28^{\circ} 35^{\prime}$ and $29^{\circ} 10^{\prime} \mathrm{E}$ longitude. It has elongated shape, was affected by tectonic activity along the Syrian Arc fold system, and shows two opposite plunging anticlines: Ghorabi in the north and El-Heiz in the south, and El-Hufhuf syncline in between, trending NE-SW (Sehim, 1993; Fig. 1). The geology of the oasis has been dealt by many authors: (Ball and Beadnell, 1903; Said, 1962; El-Akkad and Issawi, 1963; Tanner and Khalifa, 2010). It's exposed thick succession ranging from Upper Cretaceous to Miocene in age. The 
Upper Cretaceous is represented by Bahariya Formation, El-Heiz Formation, El-Hufhuf Formation and Khoman Chalk Formation. The Eocene is mainly carbonate rocks with iron ores represented by Naqb El-Sillim, Qazzun and El-Hamra formations. The Oligocene is unconformably overlie Cretaceous - Eocene succession, formed of clastic facies and lava flows of Oligocene-Miocene age. Bahariya depression comprises change in lithology can be traced as we move towards south western direction.

The Bahariya Formation outcrop the Lower Cenomanian, characterized by cross-bedded and color-banding at the base of the formation, and composed of ferruginous sandstones, siltstones, and shales with maximum thickness up to $170 \mathrm{~m}$ at Gabal El-Dist (Fig. 2a). It is weathered into conical-like hills and capped by basalt sills. El-Heiz Formation consists of shale, sandy clays, calcareous sandstone, up to $40 \mathrm{~m}$ in thickness at the south of the depression, outcrop the Upper Cenomanian, (ElAkkad and Issawi, 1963). El-Hefhuf Formation (Campanian) consists of cherty dolostone with chert nodules at the base, which overlie El-Heiz Formation.

The Eocene Naqb El-Sillim Formation is dolomitic and nummulitic limestones, unconformably overlies the Bahariya Formation and overlain by the Qazzun and El-Hamra Formations. ElHamra Formation is represented by mixed carbonate-clastic lithologies (Fig. 2f).
The Oligocene is represented by Radwan Formation occurring as small outcrops, composed mainly of quartz arenite and quartizitic sandstone.

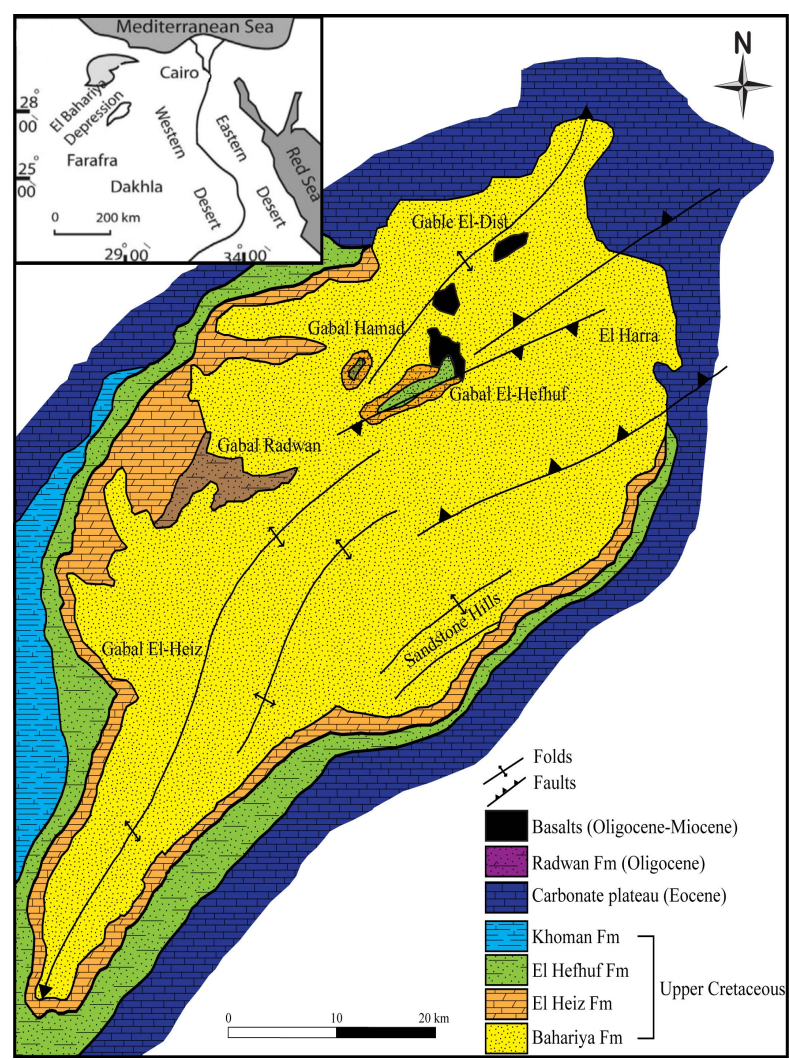

Fig. 1: Geologic map of the Bahariya Depression, Western Desert, Egypt (based on El-Akkad and Issawi, 1963).

The Oligocene-Miocene volcanic rocks occur mainly as sills, dikes and lava flows, are just restricted in the northern part of the Bahariya depression, and have dated between 22 and $16 \mathrm{Ma}$ (Meneisy and El-Kaleubi, 1975). Volcanic activity is contemporaneous with the Red Sea rifting and the uplifting of the Afro-Arabian dome (Abdel 
Meguid et al., 1992). The volcanic rocks are represented by five main separate localities of Gabal Mandisha, Gabal ElHefhuf, Gabal Mayesra, Al-Agoz Hill, Gabal El-Marssos. Bahariya volcanic rocks are alkaline magma type, classified into three types amygdaloidal basalt (oldest) intruded by dolerite and followed porphyry olivine basalt covering the amygdaloidal basalt in Gebel El-Hefhuf. Gabal Mayesra and Mandisha characterized by absence of porphyritic basalt and deeply weathered. They are dark grey to black color, structurally controlled and characterized by sheets and columnar joints sometimes, these joints form hexagonal and regular shapes (Fig. 2b, c \& d). Petrographically, basalts are composed of plagioclase, pyroxene, olivine and opaques as accessory minerals (Fig. 2e). Chlorite and epidote occur as secondary minerals due to alteration. They show textures as porphyritic, amygdaloidal, ophitic and subophitic.

\section{Materials and Methods}

Basalts, limestones and shale samples were collected from Bahariya area, are crushed to 200-mesh in ball mill (automatic Agate mortar) then made to a remix by specific weight percentages. One sample of ordinary Portland clinker (limestone \& clay) and five sample experimental clinkers (limestone and basalt) are prepared by using a computational software program according to ES 4756-1 \& EN 197-1 Standard (ES: Egyptian Specification EN: Egyptian Norm). The applied methods and techniques were conducted

in the Department of Geology, Faculty of Sciences, Al-Azhar University, Egypt.
The raw mixtures samples were pressed to form pellets, then burnt at $1450^{\circ} \mathrm{C}$ for $2 \mathrm{hrs}$, using a temperature rate raising equal to $10^{\circ} \mathrm{C} / \mathrm{min}$ in an electrical furnace in the Centre of Metals in ElTibbin, Egypt and cooled rapidly in air to preserve the newly formed cement minerals.

Complete chemical analysis of different raw material used in clinker and chemical parameters of raw-mixture are presented in Table 1. X-Ray Diffraction patterns (XRD) and Differential thermal analyses (DTA) of different clinker samples were conducted in the Housing and Building National Research Center laboratories, Egypt to determined their mineralogical composition and thermal behavior. Scanning Electron Microscope (SEM - EDX) at the Egyptian Mineral Resources Authority in Central Laboratories by using SEM Model Quanta 250 FEG (Field Emission Gun) attached with EDX Unit (Energy Dispersive X-ray Analyses), with accelerating voltage 30 K.V., magnification $14 \mathrm{x}$ up to 1000000 and resolution for Gun.1n).

\section{Geochemical characteristics}

The result of chemical analyses of seven representative samples of Eocene limestone, shale and basalt are presented in Tables (2). The chemical data of limestone of the Naqb El-Sillim Formation indicate the high $\mathrm{CaO}(54.86$ wt.\%) and low $\mathrm{MgO}$ (0.83 wt.\%). The basaltic rocks have $\mathrm{SiO}_{2}$ values vary between $48.57 \mathrm{wt} \%$ and $50 \mathrm{wt} \% . \mathrm{Al}_{2} \mathrm{O}_{3}$ ranges from $15.39-17.06 \mathrm{wt} \%$ and $\mathrm{MgO}$ is between $3.6 \mathrm{wt} \%$ and $5.38 \mathrm{wt} \%$. Loss on ignition is high values vary from 9 to 10.86 wt $\%$ suggest an intense weathering alteration to hydrous minerals. The bulk rock $\mathrm{Fe}_{2} \mathrm{O}_{3} / \mathrm{MgO}$ 
ratio ranges from 1.8-2.18 (Tables 2), indicating that the basalts are mildly differentiated.
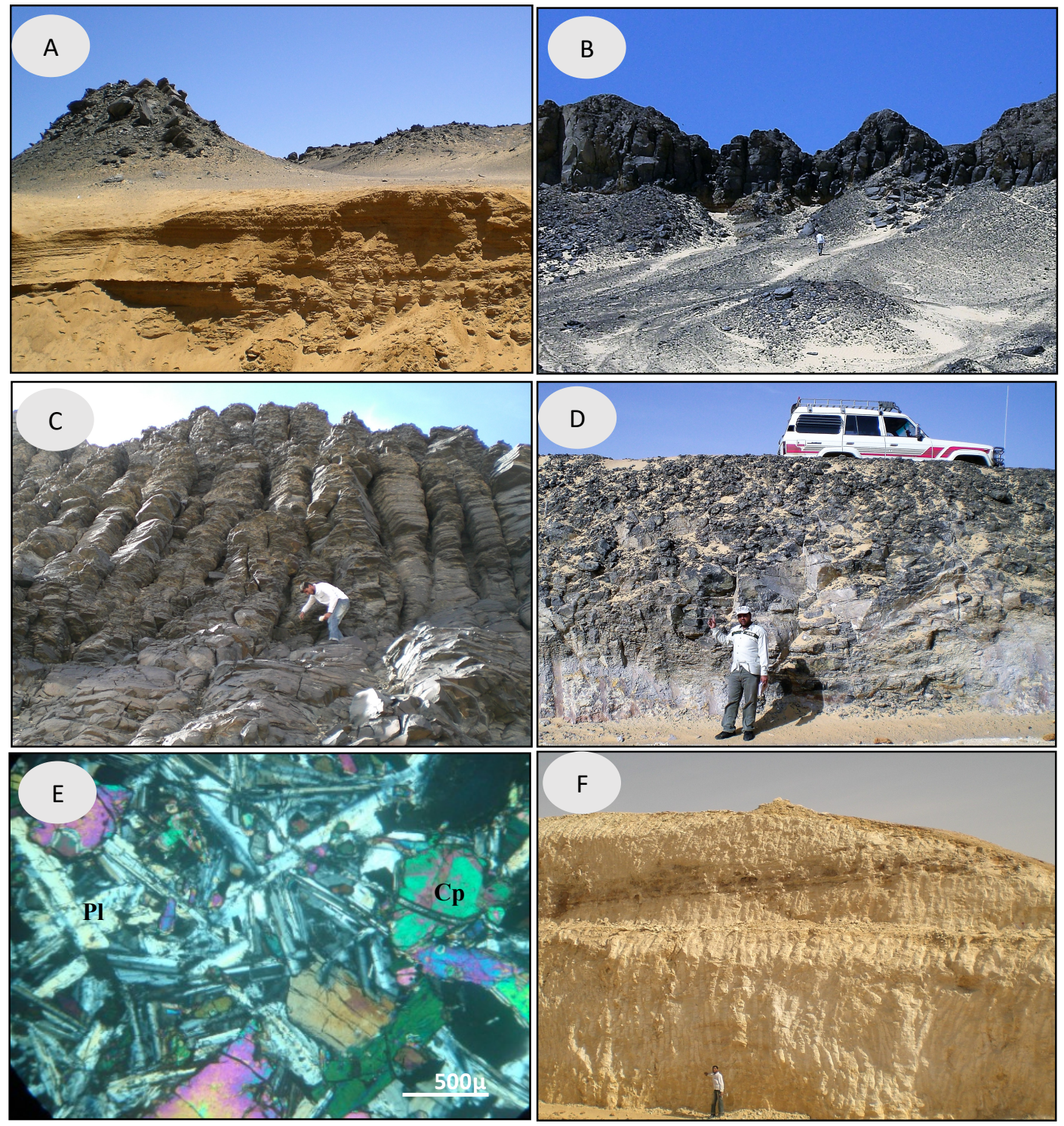

Fig. 2: Photographs showing (a) Nonconformity contact between basalt and sandstone (Cenomanian) of Bahariya Fm at Gabal Mandisha. (b) Basaltic flows are overlying Bahariya Fm at Gabal Al-Agoz. (c) Close-up view of columnar basalts in the Gabal Mandisha (d) Basalt flow with vertical and horizontal joints from Nagb Siwa (Quzzeih) (e) Photomicrograph showing plagioclase (Pl) and clinopyroxene (Cpx) laths displaying intergranular textures (C.N.). (f) Photographs showing nummulitic limestones of Lower Eocene Naqb El-Sillim Formation.

The $\mathrm{Na}_{2} \mathrm{O}+\mathrm{K}_{2} \mathrm{O}$ versus $\mathrm{SiO}_{2}$ classification diagram of $\mathrm{Cox}$ et al., (1979) shows that the studied samples are falling in the fields of basalt (Fig. 4a).
$\left(\mathrm{Na}_{2} \mathrm{O}+\mathrm{K}_{2} \mathrm{O}\right)$ diagram suggested by Irvine and Baragar (1971), to distinguished between the alkaline and 
sub-alkaline nature of magma, the examined samples have sub-alkaline affinity (Fig. 4b). On the AFM diagram of Irvine and Baragar (1971), proposed as a method of discrimination between calc-alkaline and tholeiitic affinity the samples have an Fe enrichment trend and plot in the tholeiitic field (Fig. 4c).

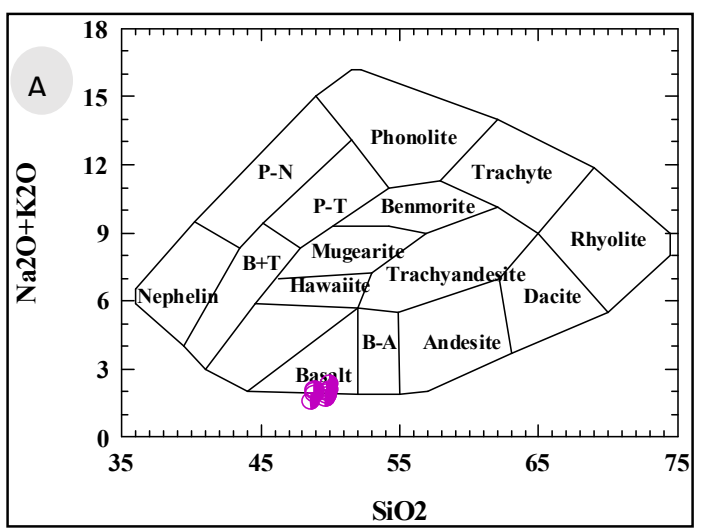

The prevailing of the concept of orogenic tectonic setting of the examined basaltic rocks have coincided owing their representation and plotting on the On $\mathrm{FeO}^{\mathrm{t}}-\mathrm{MgO}-\mathrm{Al}_{2} \mathrm{O}_{3}$ ternary diagram proposed by Preace and Gale (1977), the majority examined samples are plotted on the field of orogenic and nearby the field of continental (Fig. 4d).
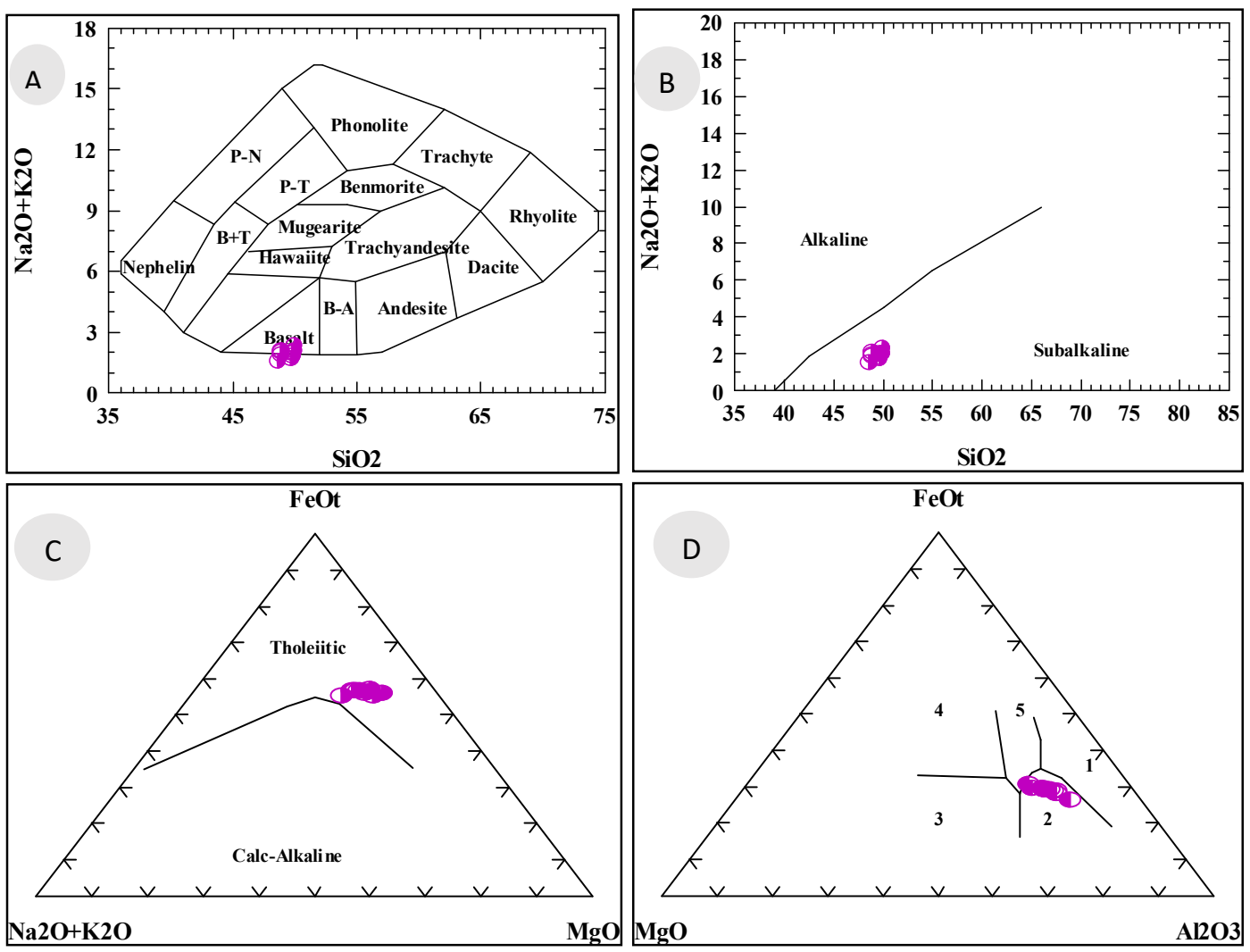

Fig. 3: a) $\mathrm{SiO}_{2}$ versus $\left(\mathrm{Na}_{2} \mathrm{O}+\mathrm{K}_{2} \mathrm{O}\right)$ classification diagram of Cox et al., (1979). b) TAS diagram of Irvine and Baragar, (1971). c) AFM diagram of Irvine and Baragar, (1971). d) The $\mathrm{MgO}-\mathrm{Al}_{2} \mathrm{O}_{3}-\mathrm{FeOt}$ tectonic discrimination diagrams of (after Pearce and Gale, 1977), (1) Spreading Center (2) Orogenic (3) Ocean Ridge (4) Ocean Island (5) Continental.

\section{Results and discussion}

The clinker contains 4 major phases; alite (C3S), belite (C2S), aluminate (C3A) and ferrite (C3AF). Clinker chemistry of Bahariya basaltic rocks (BC) is presented in Table (1).

C3S (tricalcium silicate) $\rightarrow(68 \%-69 \%)$

$\mathrm{C} 2 \mathrm{~S}$ (dicalcium silicate) $\rightarrow(17 \%-18 \%)$
$\mathrm{C} 3 \mathrm{~A}$ (tricalcium aluminate) $\rightarrow(7 \%-8 \%)$

$\mathrm{C} 3 \mathrm{AF}$ (tetracalcium aluminoferrite) $\rightarrow$ (6\%-7\%). 
Table 1. The chemical analysis of the Bahariya basaltic clinker phases (BC).

\begin{tabular}{|c|c|c|}
\hline Item & $\begin{array}{c}\text { Clinker } \\
\mathbf{( \% )} \\
\text { BC }\end{array}$ & $\begin{array}{c}\text { Ordinary } \\
\text { Portland } \\
\text { Cement (\%) } \\
\text { (OPC) }\end{array}$ \\
\hline Alite (C3S) & 62.97 & $35-70$ \\
\hline Belite (C2S) & 8.87 & $15-30$ \\
\hline $\begin{array}{c}\text { Aluminate } \\
(\mathrm{C} 3 \mathrm{~A})\end{array}$ & 9.48 & $5-10$ \\
\hline $\begin{array}{c}\text { Ferrite } \\
(\mathrm{C} 4 \mathrm{AF})\end{array}$ & 9.43 & $5-10$ \\
\hline
\end{tabular}

\subsection{Chemical analysis}

Seven samples representing of the studied raw material were analyzed by conventional wet chemical techniques (Shapiro and Brannock, 1962) for major oxide compositions are presented in Table 2. Loss on ignition (LOI) was determined by heating the powdered samples for $1 \mathrm{~h}$ at $1000{ }^{\circ} \mathrm{C}$. By comparing the chemical compositions of basalts are similar to shale. Basalts having a high content $\left(\mathrm{SiO}_{2}+\mathrm{Al}_{2} \mathrm{O}_{3}\right)$ ranging from 63.96 to $66.97 \%$ and total alkalis content (0.54-2.33), whereas the lime is less than $9 \%$.

The raw-mixture chemical parameters and the $\mathrm{C} 3 \mathrm{~S}$ and $\mathrm{C} 2 \mathrm{~S}$ expected percentages calculated according to modified Bogue's equations, are presented in Tables 2 and 3. Portland cement clinker is created by burning raw-mixture at about $1,450^{\circ} \mathrm{C}$ in a kiln, the raw-mixture is composed of limestone, shale, clay, iron ore etc., which composition is obtained according to a lime saturation factor (LSF), Silica ratio (SR) and alumina ratio (AR). The LSF factor is utilized to control amount of lime that can be combined with silica, alumina and ferrite during burning and cooling, ranges from $90-100$ for ordinary Portland cement (OPC) clinkers. The SR (values between 2.3 and 2.8) controls the relation between silicate phases (C3S, C2S) and interstitial phases (C3A, C4AF), while the AR (values between 1.4 and 1.6) shows nature of the viscosity of clinker melt. The calculated chemical parameters (LSF, SR, AR) for experimental clinker $(95,1.88-1.93$ and 1.48-1.8 respectively) are similar to ordinary clinker. Experimental clinkers exhibit display slightly higher $\mathrm{C} 3 \mathrm{~S} / \mathrm{C} 2 \mathrm{~S}$ as compared to ordinary clinker.

\subsection{Mineralogy of experimental clinkers}

XRD analyses have been carried out on the clinker samples, which are one sample ordinary Portland clinker and other samples for experimental clinker. The samples grinding to 200 -mesh in ball mill (automatic Agate mortar), that were analyzed by XRD. X-ray diffraction analysis established using Panalytical X'PERT PRO type with $\mathrm{Cu}$ Ka radiation, tube electric current $30 \mathrm{~mA}$ and tube voltage $40 \mathrm{kV}$, and scanning speed $4 \% \mathrm{~min}$.

The mineralogical composition of experimental clinker comprises from XRD pattern (Fig. 4a, b, c, d \& e). It shows the presence of calcium silicates (alite and belite) as the main mineral, portlandite present as an additive from free lime, calcite, quartz and vermiculite are also present as minor constituents. The ordinary clinker shows similar XRD pattern (Fig. 4f) with experimental clinkers

According to the XRD findings, $\mathrm{C} 3 \mathrm{~S}, \mathrm{C} 2 \mathrm{~S}$, and $\mathrm{C} 3 \mathrm{~A}$ were the majority crystalline phases in both the experimental and ordinary clinkers. Alite is detected by XRD in the clinker through the d-spacing $2.764 \AA$ Á the alite lines coincides with the lines of belite $(\beta$ 
$-\mathrm{C} 2 \mathrm{~S})$. Belite (C2S) is the second phase in intensity which identified from X-ray chart using lines at $2.76 \AA \hat{A}, 2.88 \AA$ for $\alpha$ -

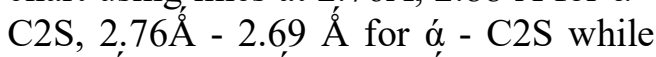

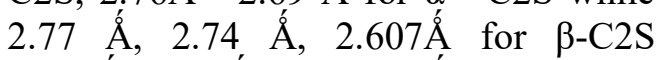
$3.002 \AA \hat{A}, 2.77 \AA$ a and $1.98 \AA \AA$ for $\delta$-C2S. The aluminate phase $(\mathrm{C} 3 \mathrm{~A})$ has been

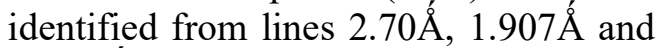
1.566 Á.

The XRD analysis confirm the formation of $\mathrm{C} 3 \mathrm{~S}$ formation of $\mathrm{C} 3 \mathrm{~S}$ at around $1,300^{\circ} \mathrm{C}$ for basalt-contain raw as compared to the raw mix without basalt which showed the C3S peak at a much higher temperature according to Khadilkar et al., (1989).

Table 2. Chemical analyses of the Bahariya basaltic raw materials (major oxides wt $\%$ ), basaltic clinkers and chemical parameters of raw-mixtures.

\begin{tabular}{|c|c|c|c|c|c|c|c|c|c|}
\hline Oxides & \multicolumn{5}{|c|}{ Basalt } & \multirow{2}{*}{$\begin{array}{c}\text { Lime- } \\
\text { stone }\end{array}$} & \multirow{2}{*}{$\begin{array}{l}\text { Shale } \\
54.84\end{array}$} & \multirow{2}{*}{$\begin{array}{c}\begin{array}{c}\text { Basaltic } \\
\text { clinker } \\
\%\end{array} \\
20.58\end{array}$} & \multirow{2}{*}{$\begin{array}{c}\text { Shale } \\
\text { Clinker } \\
\% \\
20.41\end{array}$} \\
\hline $\mathrm{SiO}_{2}$ & 49.93 & 49.91 & 49.6 & 49.75 & 48.57 & & & & \\
\hline $\mathbf{A l}_{2} \mathbf{O}_{3}$ & 16.32 & 17.06 & 15.75 & 15.52 & 15.39 & 1.38 & 25.01 & 6.93 & 8.61 \\
\hline $\mathrm{Fe}_{2} \mathrm{O}_{3}$ & 8.92 & 8.15 & 9.37 & 9.34 & 9.74 & 1.13 & 5.91 & 3.85 & 2.99 \\
\hline $\mathrm{CaO}$ & 8.34 & 7.65 & 8.85 & 8.77 & 7.64 & 54.86 & 2.85 & 64.88 & 65.78 \\
\hline MgO & 4.09 & 3.6 & 4.65 & 4.66 & 5.38 & 0.83 & 1.39 & 2.08 & 1.37 \\
\hline $\mathrm{SO}_{3}$ & 0.63 & 0.7 & 0.86 & 0.64 & 0.74 & 0.015 & 0.62 & 0.24 & 0.19 \\
\hline $\mathrm{Na}_{2} \mathrm{O}$ & 1.83 & 2.08 & 1.44 & 1.83 & 1.28 & 0.43 & 0.94 & 90 & 0.77 \\
\hline $\mathbf{K}_{2} \mathbf{O}$ & 0.22 & 0.25 & 0.28 & 0.19 & 0.27 & 0.11 & 0.15 & 0.10 & 0.17 \\
\hline CI & 0.13 & 0.71 & 0.38 & 0.11 & 0.26 & 0.1 & 0.39 & 0.34 & 0.23 \\
\hline LOI & 10.01 & 9.93 & 9 & 10 & 10.86 & 37.02 & 9 & -- & -- \\
\hline Total & 100 & 100 & 100 & 100 & 100 & 100 & 100 & -- & -- \\
\hline $\begin{array}{l}\mathrm{Fe}_{2} \mathrm{O}_{3} / \\
\mathrm{MgO}\end{array}$ & 2.18 & 2.26 & 2.02 & 2.00 & 1.81 & -- & -- & -- & -- \\
\hline \multicolumn{10}{|c|}{ Chemical parameters } \\
\hline LSF & 95 & 95 & 95 & 95 & 95 & -- & 95 & 101.33 & -- \\
\hline SR & 1.91 & 1.91 & 1.91 & 1.93 & 1.88 & -- & 1.76 & 2.34 & -- \\
\hline $\mathbf{A R}$ & 1.64 & 1.80 & 1.54 & 1.53 & 1.48 & -- & 2.88 & 1.29 & -- \\
\hline C3S (\%) & 56.66 & 55.69 & 57.00 & 57.45 & 56.97 & -- & 50.57 & 62.97 & -- \\
\hline C2S (\%) & 16.47 & 16.99 & 16.06 & 16.01 & 15.82 & -- & 20.35 & 8.87 & -- \\
\hline $\mathrm{C} 3 \mathrm{~S} / \mathrm{C} 2 \mathrm{~S}$ & 3.4 & 3.3 & 3.5 & 3.6 & 3.6 & -- & 2.5 & 7.10 & -- \\
\hline
\end{tabular}

Code: LOI: Loss on ignition, LSF: lime saturation factor, SR: silicate ratio, AR: aluminate ratio, $\mathrm{C} 3 \mathrm{~S}$ : alite, $\mathrm{C} 2 \mathrm{~S}$ : belite. 


\subsection{Thermal properties of the experimental clinkers}

Differential thermal analysis (DTA) was utilized to distinguish the phases transformation of the raw materials during the sintering process and the reaction temperatures, and evaluated the minerals during clinker formation. Alite formed at exothermal peaks of $1250^{\circ} \mathrm{C}$ and at $1175^{\circ} \mathrm{C}$ was credited to the development of belite while decarbonation happened at about $650^{\circ} \mathrm{C}$. Basalts are characterized by fluxes of the melt and facilitate the clinkerization at lower temperatures.

Figure (5a, b, c, d \& e) illustrates the DTA thermograms of the experimental clinkers, while ordinary clinkers (Fig. 5f). The curves represent two endotherms at $60-72^{\circ} \mathrm{C}$ and 759 $829^{\circ} \mathrm{C}$. The first endothermic peak is the dihydroxylation of metasilicate (olivine, amphiboles and chlorite; Abd El-Hafiz et al., 2015; El-Desoky et al., 2019; ElDesoky et al., 2019; El-Rahmany et al., 2019; El-Rahmany et al., 2020). The second endothermic peak is corresponding to the release of $\mathrm{CO}_{2}$ due to the decomposition of $\mathrm{CaCO}_{3}$ (Tsakiridis et al., 2014; El-Didamony et al., 2015; Khalil, 2016). On the other hand, the phase transformation appeared as a flat wide band, instead of the expected endothermic peaks. The last exothermic peak should be attributed to the formation $\mathrm{Ca}_{3} \mathrm{SiO}_{5}$ (alite). The peak areas showed up in the thermograms obtained for experimental clinkers are almost indistinguishable to those of the ordinary clinkers. The results of DTA are correspondence with those of XRD and chemical analysis.

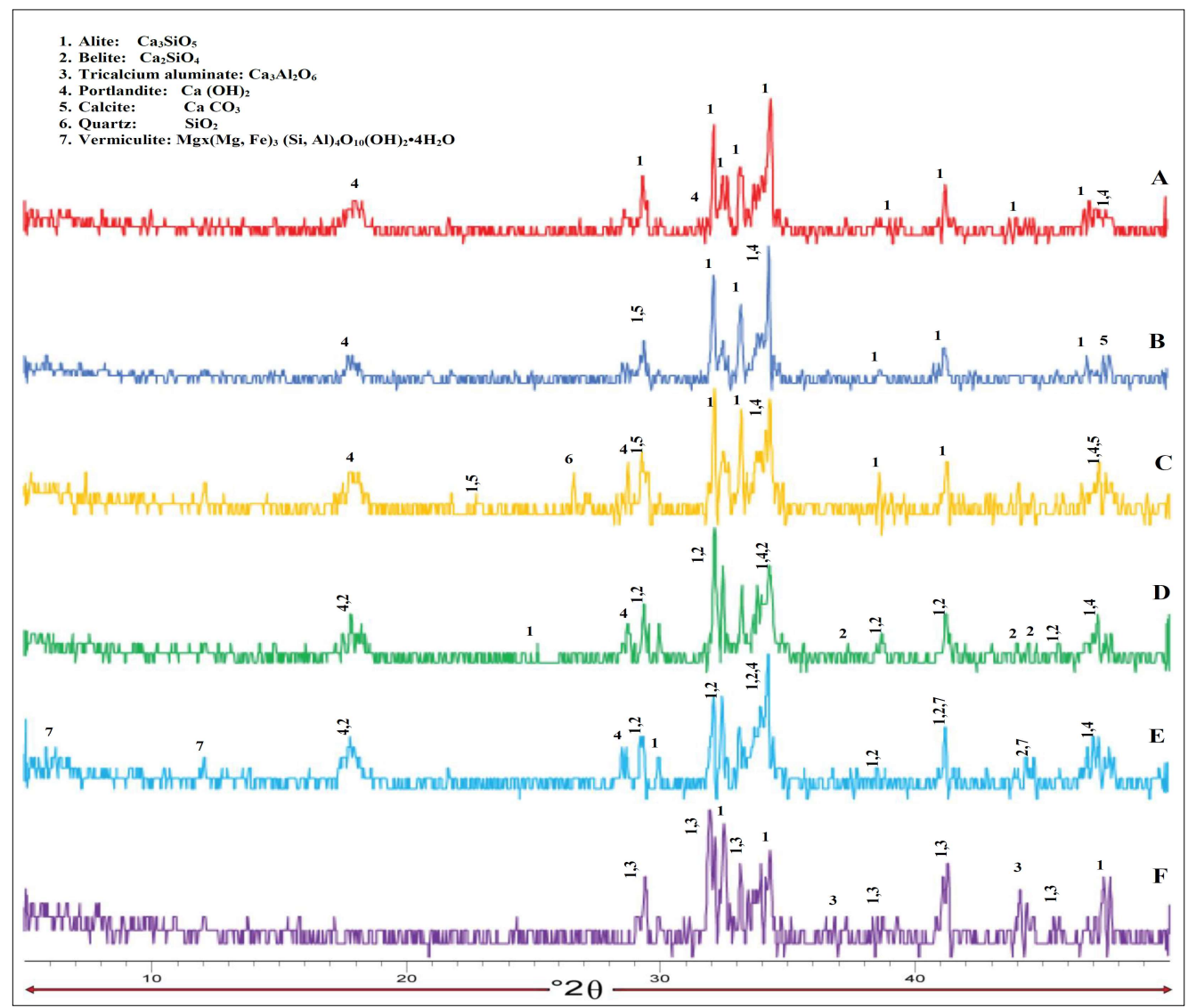

Fig. 4: XRD pattern of the experimental clinker basalt (a, b, c, d \& e) and ordinary Portland clinker (f). 


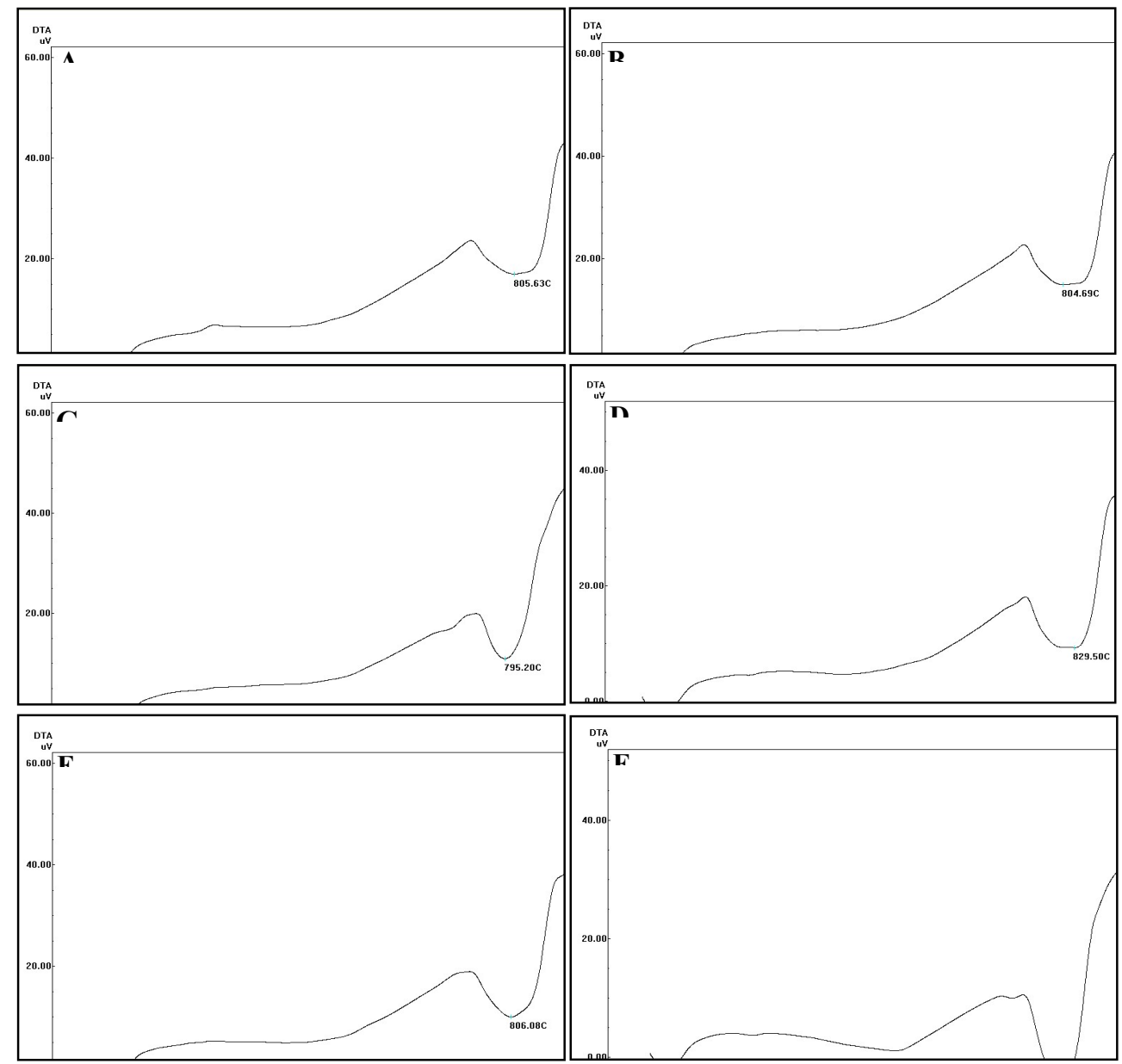

Fig. 5: DTA curves of the experimental clinker (A-E) basalt raw material (1-5) and (F) ordinary Portland clinker (6).

\subsection{SEM examinations of the experimental basaltic clinkers}

The Scanning Electronic Microscopic (SEM-EDX) was used to study the morphology and chemical composition of experimental cement clinker, one ordinary cement clinker as a reference sample. The main minerals constitute the cement clinker are alite $\left(\mathrm{Ca}_{3} \mathrm{SiO}_{5}\right)$ and belite $\left(\mathrm{Ca}_{2} \mathrm{SiO}_{4}\right)$. Fig. (6) showed a backscattered electron images

crystals of hexagonal shape, whereas belite is fine rounded crystals, as well as aluminate is fine grained embedded in the matrix. A typical EDX spectrum experimental cement clinker shows high picks for the elements $\mathrm{Ca}$ and $\mathrm{Si}$ and lower picks for the other elements (Fig. 6). The chemical analyses of the experimental cement clinker show high 
content of $\mathrm{CaO}$ up to $(66.81 \%)$ and $(79.02 \%)$, respectively. The amount of $\mathrm{SiO}_{2}$ varies from $(17.88 \%-20.79 \%)$, $\mathrm{Al}_{2} \mathrm{O}_{3}$ reaching about $(3.8 \%-6.46 \%)$, $\mathrm{K}_{2} \mathrm{O}$ content ranges between $(0.72 \%)$ and $(0.97 \%), \mathrm{FeO}$ up to $(3.6 \%), \mathrm{MgO}$ up to $(2.5 \%)$ and $\mathrm{SO}_{3}$ up to $(1.5 \%)$,
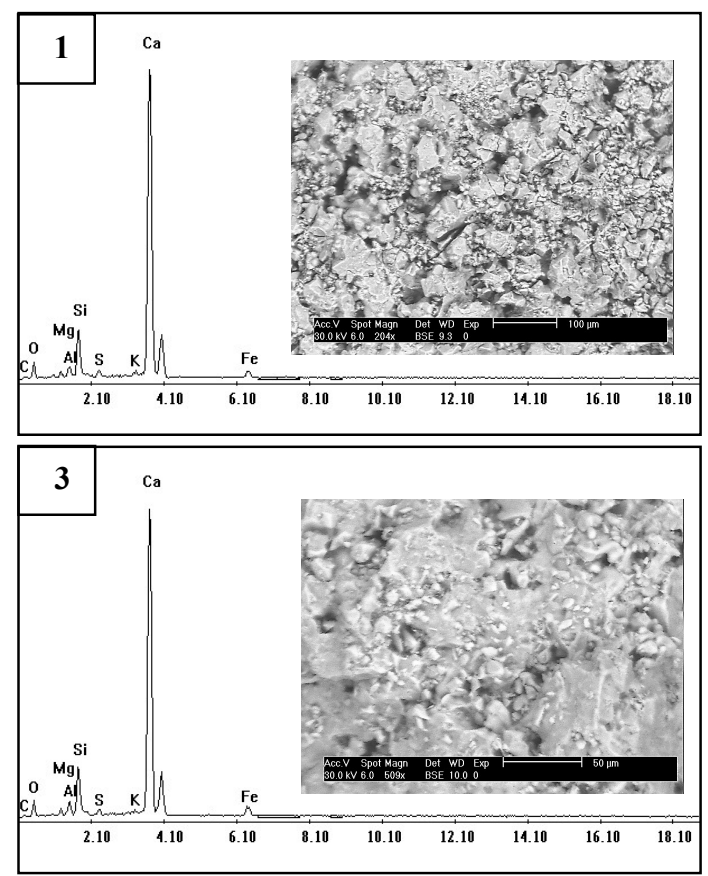

respectively. The results of experimental clinker are coincidence with the molecular structure analysis (Bogue's calculation) of ordinary clinker and percentages of $\mathrm{C} 3 \mathrm{~S}$ and $\mathrm{C} 2 \mathrm{~S}$ are normal ranges with a slight change.
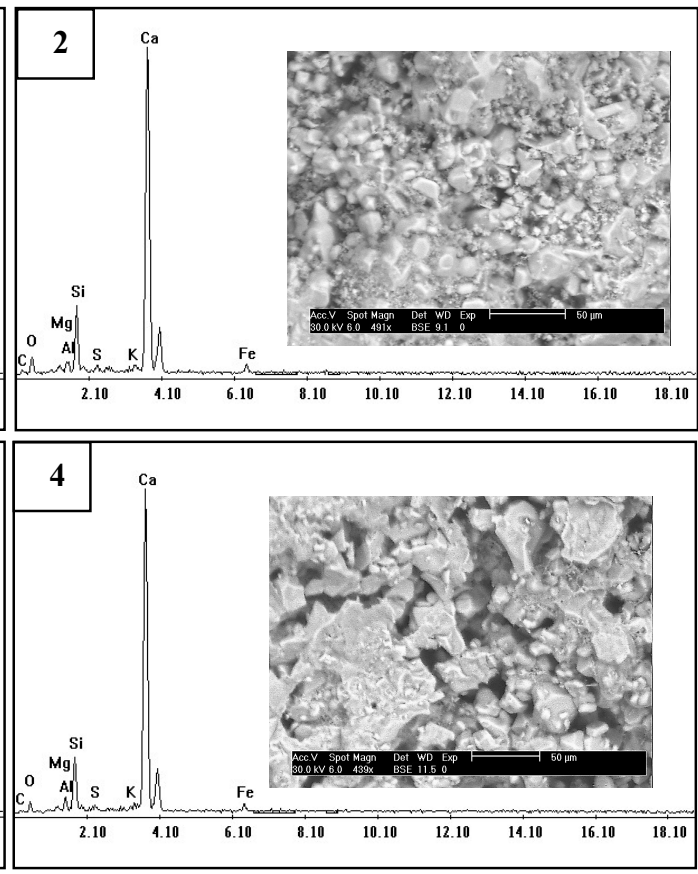

Fig. 6: EDX and BSE image showing chemical composition and morphology of experimental cement clinker. EDX = Energy dispersive X-ray, BSE = Back scattered electron image.

\subsection{Cement Production}

The cement samples are prepared by crushing the basaltic clinker specimens with small amount of the gypsum material in machine mill. The chemical analysis of the basaltic clinker cement samples is presented in Table (3). Gypsum is added to basaltic clinker cement mainly for the purpose of regulating its setting time, prevents flash setting and makes the gabbroic clinker cement concrete workable for hours (Gebauer, 1978).

Ordinary Portland Cement (OPC) by far the most frequently used type of cement consists mainly of the four major chemical components (Mueller et al., 1978): -

- Calcium oxide $\quad 64 \% \quad \mathrm{CaO}$

"Calcium", C

- Silicon oxide $\quad 22 \% \quad \mathrm{SiO}_{2}$

"Silica", S

- Aluminum oxide $\quad 6 \% \quad \mathrm{Al}_{2} \mathrm{O}_{3}$

"Alumina", A

- Iron oxide $\quad 3 \% \quad \mathrm{Fe}_{2} \mathrm{O}_{3}$

"Iron" F

$\mathrm{Na}_{2} \mathrm{SO}_{4}$ and $\mathrm{K}_{2} \mathrm{SO}_{4}$ accelerate the hydration of $\mathrm{C} 3 \mathrm{~S}$ and give rise to enhanced 2-days and 7-days strength but diminish the 28-days compressive strength. The degree of hydration decreases with increase of alkali oxide content. The increasing of $\mathrm{SO}_{3} \%$ (about $1.86-0.65 \%$ ) in clinker causing 
expansion of the concrete, slowing setting and reduction of strength where the strength decreases with increasing $\mathrm{SO}_{3} \%$. The higher alkalies $(>1 \%)$ in basaltic clinker cause expansion of cement and reduce the compressive strength and high chloride also cause reduces the strength and form rust in the steel due to reaction between chloride (Gebauer, 1978).

\subsection{Physical and mechanical characteristics}

The physical properties of rocks are as important as the chemical characteristics because they are determining factors in the choice of method and technique of raw material transportation, exploitation, communities and blending communities. Therefore, they affect the manufacturing process.

The development of strength values is affected by the mineralogical structure of clinkers, pozzolanic reactions, Blaine and water demand as strength of cements is a function of the hydrated section (Lea, 1970).

The setting time is the time when the cement paste begins losing its

Table 3. Shows the chemical analyses and parameter of clinker from Bahariya basaltic rocks (BC), the clinker by using shale at Tourah (TP) plants, Qattamiya plants (QP), standard of clinker by using shale in the world (Hewlett, 1997) and basaltic clinker (Hassaan, 2001; Abd-El-Hafiz et al., 2015; El-Desoky et al., 2017).

\begin{tabular}{|c|c|c|c|c|c|c|c|}
\hline $\begin{array}{c}\text { Oxides } \\
(\mathbf{\%})\end{array}$ & $\mathbf{B C}$ & $\mathbf{T P}$ & $\mathbf{Q P}$ & $\begin{array}{c}\text { Hewlett } \\
(\mathbf{1 9 9 7 )}\end{array}$ & $\begin{array}{c}\text { Hassaan } \\
(\mathbf{2 0 0 1})\end{array}$ & $\begin{array}{c}\text { Afifi } \\
(\mathbf{2 0 1 5})\end{array}$ & $\begin{array}{c}\text { El-Desoky } \\
(\mathbf{2 0 1 7})\end{array}$ \\
\hline $\mathbf{S i O}_{\mathbf{2}}$ & 20.58 & 21.43 & 21.32 & 21.70 & 21.5 & 20.71 & 22.22 \\
\hline $\mathbf{A l}_{\mathbf{2}} \mathbf{O}_{3}$ & 6.93 & 5.81 & 5.47 & 5.54 & 5.7 & 6.54 & 4.9 \\
\hline $\mathbf{F e}_{\mathbf{2}} \mathbf{O}_{3}$ & 3.85 & 4.24 & 4.31 & 2.15 & 4.8 & 4.85 & 4.44 \\
\hline $\mathbf{C a O}$ & 64.88 & 62.83 & 64.35 & 67.10 & 63.9 & 63.50 & 64.16 \\
\hline $\mathbf{M g O}$ & 2.08 & 2.37 & 1.59 & -- & 2.7 & 2.52 & 2.45 \\
\hline $\mathbf{S O}_{3}$ & 0.24 & 0.32 & 1.21 & 1.00 & 1.2 & 0.16 & 0.12 \\
\hline $\mathbf{K}_{2} \mathbf{O}$ & 0.10 & 0.05 & 0.27 & -- & -- & 0.06 & 0.61 \\
\hline $\mathbf{N a}_{2} \mathbf{O}$ & 0.90 & 0.00 & 0.50 & -- & -- & 0.32 & 0.53 \\
\hline $\mathbf{C l}$ & -- & 0.00 & 0.01 & -- & -- & 0.01 & 0.10 \\
\hline $\mathbf{L O I}$ & -- & 0.55 & 0.36 & -- & -- & 0.42 & -- \\
\hline $\mathbf{T o t a l}$ & - & - & 99.39 & -- & -- & -- & -- \\
\hline $\mathbf{L S F}$ & 101.33 & 0.902 & 0.931 & 0.975 & 0.912 & 0.92 & 91.69 \\
\hline $\mathbf{S R}$ & 2.34 & 2.13 & 2.18 & 2.82 & 2.04 & 1.82 & 2.36 \\
\hline $\mathbf{A R}$ & 1.29 & 1.37 & 1.27 & 2.58 & 1.18 & 1.35 & 1.12 \\
\hline $\mathbf{C 3 S}$ & 62.97 & - & 51.37 & 65 & 37.5 & -- & 57.66 \\
\hline $\mathbf{C 2 S}$ & 8.87 & - & 22.45 & 14 & 33.4 & -- & 19.15 \\
\hline $\mathbf{C 4 A F}$ & 9.43 & - & 13.10 & 6.5 & - & -- & 14.5 \\
\hline $\mathbf{C 3 A}$ & 9.48 & - & 7.21 & 11.0 & 7.1 & -- & 5.4 \\
\hline
\end{tabular}

1- Bahariya basaltic samples (BC).

2- The chemical analysis of clinker by using shale at Tourah plants (TP).

3- The chemical analysis of clinker by using shale at Qattamiya plants (QP).

4- Standard of clinker by using shale in the world (Hewlett, 1997).

5- The chemical analysis of basaltic clinker according to Hassaan (2001).

6- The clinker sample of the Naqb Ghoul basalts and Ghribun limestone (Abd El-Hafiz, 2015).

7- The chemical analysis of basaltic clinker according to El-Desoky (2017). 
The setting time test of prepared cement, about $300 \mathrm{~g}$ is mixed with about $26 \%$ water to form Portland cement paste and pouring in the mold cylinder (disk) and put in vessel (basin) water to measurement and determine initial and final of the setting time (Table 4).

The setting time data of the prepared cement specimens reveal initial and final setting time of the Bahariya basaltic (BC) are 145 and 190 minutes respectively. The initial and final setting times were prolonged for basalt cement than the cement paste because of tricalciumsilicate (C3S) which gives the hardening and compressive strength of paste at early age (Laibao et al., 2013). The results showed that the initial and final setting times of prepared cement are consistent with standard Portland cement paste data, which refer to the prepared cement specimens are suitable and normal for the concretes.

Compressive strength test, about $450 \mathrm{gm}$ of prepared cement $(450 \mathrm{gm})$ is mixed with sand (1350gm) and $225 \mathrm{ml}$ water in the mixer machines to form mortar homogenization. The specimen mortar is pouring in the concrete cubic mold and then compact by vibrating machine and put in stored in circulating water at about $20^{\circ} \mathrm{C}$ and $97 \%$ humidity during 2days, 7days and 28 days. The specimens removed from water to measure a compressive strength by a compression machine according to the ES: 4756-1 \& EN 197-1 Standard (CEM1-42.5N; Table 5). The values of compressive strength of prepared cement showed a marked increase continuously with the time of hydration, which lead to increase the compressive strength as result of formation such as $\mathrm{CSH}$ during hydration proceeds.
Table 4. Setting time of the prepared cement samples from grinding Bahariya basaltic (BC) clinker with gypsum.

\begin{tabular}{|l|c|c|c|c|}
\hline Samples & $\begin{array}{c}\text { Standard } \\
\text { Consistency \% }\end{array}$ & $\begin{array}{c}\text { Initial } \\
\text { Setting } \\
\text { time }\end{array}$ & $\begin{array}{c}\text { Final } \\
\text { Setting } \\
\text { time }\end{array}$ & Specification \\
\hline $\begin{array}{l}\text { Bahariya } \\
\text { basaltic } \\
\text { (BC) }\end{array}$ & 25.25 & $\begin{array}{c}145 \\
\text { Minutes }\end{array}$ & $\begin{array}{c}190 \\
\text { Minutes }\end{array}$ & $\geq 60 \mathrm{~min}$. \\
\hline
\end{tabular}

Table 5. The compressive strength data of the prepared cement samples from grinding Bahariya basaltic (BC) clinker with gypsum and sand.

\begin{tabular}{|c|c|c|}
\hline Strength & $\begin{array}{c}\text { Bahariya } \\
\text { basaltic } \\
\text { (BC) }\end{array}$ & Specification \\
\hline 2 Days N/mm² & 17.14 & $\geq 10$ \\
\hline 7 Days N/mm² & 26.98 & \\
\hline 28 Days $\mathbf{N} / \mathbf{m m}^{2}$ & 44.18 & $>42.5$ \\
\hline
\end{tabular}

\section{Conclusion}

- Volcanic activity in the Western Desert is restricted anorogenic continental rifting. They exposed as flood basalts sheets capping hills of Oligocene sands and gravels.

- Basalt is recognized as an alternative raw-material for Portland cement recently, especially substitute for clay in a 1:1 proportion.

- Basalt with relatively high content of iron oxides reduces the heat consume to form the clinker flux agent.

- The mineralogical compositions of the basaltic clinker using X-ray diffraction indicated that it mainly composed of alite (C3S), belite (C2S) and Aluminate (C3A) which coincidence ordinary Portland clinker.

- Basalt can be used raw material for cement clinker production. It is better than clay in cement clinker manufacture because it is promoting the consumption of free lime and improves the burnability. 
- Basaltic cement clinker has preferable physicomechanical properties consistent with ordinary cement clinker, that was found to be suitable for construction applications.

\section{References}

Abd El-Hafiz, N.A., Abd El-Moghny, M.W., El-Desoky, H.M., Afifi, A.A., 2015. Characterization and technological behavior of basalt raw materials for Portland cement clinker production. IJISET International Journal of Innovative Science, Engineering \& Technology, Vol. 2 Issue 7, July 2015.

Abdel Meguid, A., El-Mettwally, A., Morsy, M., 1992. Tectonic evolution of continental basalts of Egypt: geochemical evidences. Egypt. Mineral., vol. 4, p.141-158.

Andrade, F.D., Pecchio, M., Bendoraitis, D.P., Montanheiro, T.J., Kihara, Y., 2010. Basalt mine-tailings as rawmaterials for Portland clinker. Cerâmica, 56(337), 39-43.

Ball, J., Beadnell, H.J.L., 1903. Baharyia Oasis: its Topography and Geology. Geological Survey of Egypt, Cairo, p. 84.

Cox, K.G., Bell, J.D., and Pankhurst, R.J., 1979. The interpretation of igneous rocks. London. Allen and Unwine, $450 \mathrm{p}$.

El-Akkad, S., Issawi, B., 1963. Geology and iron ore deposits of the Bahariya Oasis. Geol. Surv. Egypt, Cairo, p. 300. Paper 18.

El-Ashkar, A.A.A., 2002. Studies on mineralogical, geochemical and physical characteristics on basalts of Cairo-Suez road for evaluation for using in cement industry. B.Sc. Thesis, Faculty of Science, El-Azhar University, p. 59-103.

El-Desoky, H.M., Zidan, I.H., El-shafey, R.E., 2017. Appraisal of sedimentary and volcanic rocks at Al-Hemmah-Resan Ikteifa district, North Sinai, Egypt as raw materials in Portland cement clinker production. International Journal of Innovative and Applied Research ISSN 2348 - 0319. Volume 5, Issue 2. P. 5-25.

El-Desoky, H.M., Afifi, A.A., Heikal, M.A., Abdel-Rahman, A.M., 2019. The use of Egyptian gabbroic rocks from Wadi Allaqi district in cement clinker production. Annals Geol. Surv. Egypt. V. XXXIV (2019), pp. $941-165$.

El-Didamony, H., Helmy, I.M., Osman, R.M., Habboud, A.M., 2015. Basalt as Pozzolana and Filler in Ordinary Portland Cement. American Journal of Engineering and Applied Sciences, 8 (2): 263-274.

El-Rahmany, M.M., Mira, H.I., ElDesoky, H.M., Afifi, A.A., Fahmy, W.M., 2019. Technical and mineralogical assessment of gabbroic and basaltic rocks for cement clinker production. Annals Geol. Surv. Egypt. V. XXXIV, pp. $205-221$.

El-Rahmany, M.M., El-Desoky, H.M., Afifi, A.A., El-Sherif, A.M., ElAwny, H.M., 2020. Characterization and technical behavior of gabbroic rocks in Portland cement clinker production, Wadi Khashir District, Southern Eastern Desert, Egypt. Annals Geol. Surv. Egypt. V. XXXVII (2020), pp. 177 - 193.

Gebauer, J., 1978. Cement course Materials Technology. Cement "Holderbank" Management and Consulting Ltd. Technical Center-Materials Division.

Hassaan, M.Y., 2001. Basalt rock as an alternative raw material in Portland cement manufacture. Materials Letters 50, 172-178.

Hassaan, M.M., El-Sheshtawi, Y.A., Hassaan, M.Y., Al-Ashkar, A., 2004, Basalt: An Alternative to Shales in Cement Industry. Applied Mineralogy, Pecchio et al. (eds) ICAM-BR, São Paulo, ISBN 8598656-01-1. 
Hewlett, P.C., 1997. Lea's Chemistry of Cement and Concrete. 4th (ed). Elsevier Science \& Technology Books.

Irvine, T.N., and Baragar, W.R.A., 1971. $A$ guide to the chemical classification of the common volcanic rocks. Can. Jour. Earth. Sc. 8,523-548p.

Khadilkar S.A., Ghosh D. and Page C.H., 1989. Investigation on the Use of Basalt as a Corrective in Portland Cement Manufacture - A Case Study, 2nd NCB International Seminar, Vol. II, pp. V1-12.

Khalil Kh.A., 2016. Effect of Nanosilica on the Hydration Characteristics and Compressive Strength of Blended Basalt Cement Pastes. Egypt. J. Chem. 59, No. 4, pp. 573- 595.

Khan MI, Alhozaimy AM., 2010. Properties of natural pozzolan and its potential utilization in environmental friendly concrete. Can J Civ Eng; 38(1):71-8.

Lea, F.M., 1970. The Chemistry of Cement and Concrete, 3rd (ed.), Edward Arnold, London.

Laibao, L., Yunsheng, Z., Wenhua, Z., Zhiyong, L. and Lihua, Z., 2013. Investigating the influence of basalt as mineral admixture on hydration and microstructure formation mechanism of cement. Construction and Building Materials. Vol. 48: 434-440.

Mehta, P. K., 1987. Natural pozzolans: Supplementary cementing materials in concrete. CANMET Special Publication. 86: 1-33.

Meneisy, M.Y., El Kaluobi, B., 1975. Isotopic ages of the volcanic rocks of the Bahariya Oasis. Ann. Geol. Surv. Egypt 5, 119-122.

Papadakis V, Tsimas S., 2002. Supplementary cementing materials in concrete: part I: efficiency and design. Cem Concr Res; 32(10):1525-32.

Pearce T.H, Gorman B.E, Birkett T.C., 1977. The relationship between major element chemistry and tectonic environment of basic and intermediate volcanic rocks. Earth Planet. Sci. Lett. 36: 121-132.

Rodríguez-Camacho R, Uribe-Afif R., 2002. Importance of using the natural pozzolans on concrete durability. Cem Concr Res; 32(12):1851-8.

Said, R., 1962. The Geology of Egypt. Elsevier, Amsterdam, p. 377.

Sehim, A., 1993. Cretaceous tectonics in Egypt. J. Geol. 37, 335-372.

Shapiro, L., Brannock, W.W., 1962. Rapid analysis of silicate, carbonate and phosphate rocks. U.S. Geol. Surv. Bull. 1144A, 56 pp.

Tanner, L.H., Khalifa, M.A., 2010. Origin of ferricretes in fluvialmarine deposits of the lower Cenomanian Bahariya formation, Bahariya oasis, western desert, Egypt. J. Afr. Earth Sci. 56, 179-189.

Tsakiridis, P.E., Oustadakis, P., Agatzini-Leonardou, S., 2014. Black Dross Leached Residue: An Alternative Raw Material for Portland Cement Clinker. Waste Biomass Valor 5:973-983

Van Oss, H. G., Padovani A. C., 2003. Cement manufacture and the environment Part II: Environmental challenges and opportunities. J Ind Ecol; 7(1):93-126.

Uzal, B., Turanli, L., Mehta, PK., 2007. High-volume natural pozzolan concrete for structural applications. ACI Mater J; 104(5):535-8. 


\section{" استخدام بازلت البحرية كمواد بوزولانية طبيعية بديلة في صناعة كلنكر الاسمنت "البورتلاندي}

حاتم محمد الاسوقي 1, أحمد السيد خليل, طاهر محفوظ شـاهين , , احمد عبدالله3

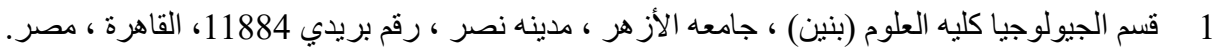

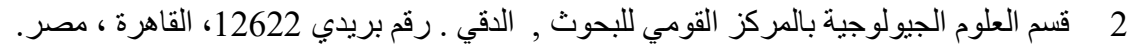
3

يرتبط النشاط البركاني في منتصف المرحلة الثالثة في الصحر اء الغربية بمصر بافتتاح البحر الأحمر

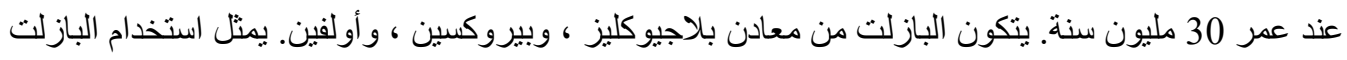
كمو اد بوزو لانية بركانية طبيعية ؛ كبديل حقيقي ليحل محل الأسمنت البورتلاندي العادي (OPC) اهتمامًا كبيرًا بالبحوث. تم تتفيذ العمل الحالي على ستة عينات من الكلنكر الأسمنتي التجريبي ، إحداها تحتوي على مو اد خام عادية (الحجر الجيري و الطفل) كعينة مرجعية ، وخمسة عينات أخرى بمواد مختلفة (الحجر الجيري

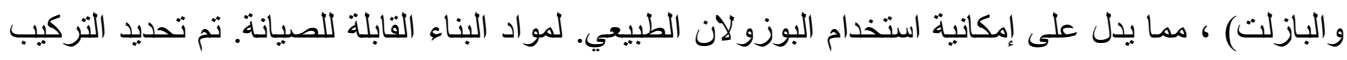

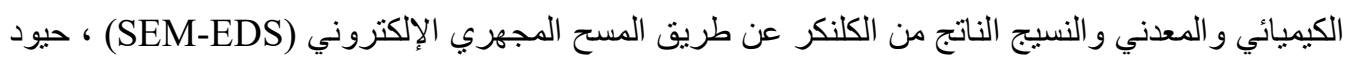

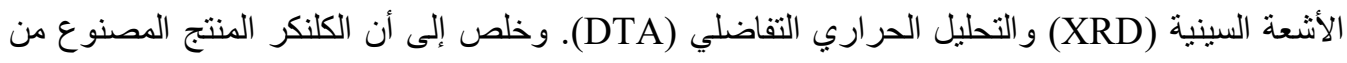
البازلت يتطابق مع كلنكر الأسمنتي البورتلاندي العادي. حيث يتميز بزيادة زمن الثك الابتدائي وقوة الانضغاط ومقاومة هجوم الكبريتات. 